\title{
Foreign versus Domestic Bribery: Explaining Repression in Kleptocratic Regimes
}

\author{
Jody LaPorte \\ Blavatnik School of Government \\ University of Oxford
}

Forthcoming at Comparative Politics, October 2017

\begin{abstract}
This article investigates variation in the governing strategies of wealth-seeking autocrats. Why do some kleptocrats grant political opponents significant leeway to organize, while others enforce strict limits on such activities? Through detailed analysis of post-Soviet Georgia and Kazakhstan, I trace variation in the intensity of repression back to differences in the sources of rulers' illegal wealth. I argue that where rulers' wealth is accumulated from society, they are constrained in their treatment of wealthy opposition leaders. In contrast, rulers who can extract bribes from foreign companies based on natural resource wealth can pursue aggressive repression without jeopardizing their illicit profits. The findings underscore the importance of rulers' motives and informal institutions in shaping non-democratic regime outcomes.
\end{abstract}


Why do some authoritarian governments repress political opposition more aggressively than others? Repression plays a key role in shaping the nature of political competition and longer-run prospects for democratization. Yet, despite renewed focus on the formal institutions of authoritarian rule, the coercive underpinnings of these regimes remain an understudied topic in comparative politics.

In this article, I investigate variation in political repression within the subset of nondemocratic regimes known as kleptocracies. In kleptocratic regimes, the ruler and his inner circle of advisers exploit their public positions to illegally extract private fortunes for themselves and their families. This article presents a paired comparison of two such regimes from post-Soviet Eurasia: Georgia under President Eduard Shevardnadze and Kazakhstan under President Nursultan Nazarbayev between 1995 and 2003. ${ }^{1}$ Georgia and Kazakhstan embarked on independent statehood in 1991 with the same set of political, economic, and social institutions inherited from the USSR. In each, a former republic first secretary exploited his nomenklatura connections to regain or retain power after independence. After initial political maneuvering, both constructed authoritarian regimes of a similar type, characterized by personalist rule, uncompetitive elections, and high corruption. They also faced formidable challenges from capitalist opposition groups in the mid-1990s, following market reforms. But these regimes responded with repression of varying intensity. In Georgia, the government pursued relatively mild repression against the capitalist opposition, involving verbal and legal harassment. In Kazakhstan, the government engaged in more aggressive campaigns against such groups, involving violence, criminal prosecution, and imprisonment.

Why would two such similar regimes pursue different approaches to dealing with their political opponents? I argue that, within kleptocracies, variation in state policies towards the 
capitalist opposition can be traced to differences in the sources of rulers' illegal wealth. In Georgia, ruling elites amassed fortunes through the collection of bribes from domestic entrepreneurs. Consequently, government officials tolerated political mobilization by those entrepreneurs in an effort to continue extracting illegal revenue. In Kazakhstan, foreign companies paid bribes in exchange for access to the country's natural resources. This revenue source allowed Kazakhstan's rulers to pursue aggressive repression against the capitalist opposition without jeopardizing their accumulation of illicit profits. In making this argument, I draw on a diverse set of sources, including sixty five original interviews conducted with government officials, opposition leaders, and political analysts in both countries. $^{2}$

Comparative analysis of these cases contributes several key theoretical insights. First, this argument advances a new perspective on politics in highly corrupt regimes. Recent work has highlighted the negative consequences of pervasive corruption. ${ }^{3}$ However, the level of graft cannot explain this divergence in political repression; corruption was widespread in both Georgia and Kazakhstan. These cases demonstrate that the source of corrupt earnings matters in explaining political outcomes. The findings bear particular relevance for arguments about the kind of political institutions that result in such regimes. Contra Acemoglu and Robinson's claim that extractive economic institutions are "synergistically linked" to exclusionary political institution, I find that this relationship is conditional. ${ }^{4}$ Under certain circumstances even a predatory ruler faces incentives to construct inclusive political institutions.

Second, the study contributes to current debates over whether corruption undermines or reinforces the integrity of authoritarian regimes. Traditional accounts suggest that state officials' pursuit of illegal wealth signals a breakdown of political authority. Other scholars have challenged this view, demonstrating that corruption can be a central tool for strengthening 
authoritarian control. ${ }^{5}$ The argument developed here suggests that this outcome is influenced, in part, by the source of rulers' illegal wealth. Specifically, the extraction of informal payments from external sources, such as foreign oil companies, may be more compatible with the development of robust authoritarian institutions than the extortion of bribes from society. These findings imply that the regime-insulating "rentier" effects of externally-generated revenue extend beyond official rents and formal state institutions.

Third, by unpacking the mechanisms of repression, this study clarifies how, when, and to what effect coercion is deployed in non-democratic regimes. Leading theories attribute variation in autocratic coercion to rulers' ability to repress, based on their organizational capacities and concern about international sanctions against such tactics. ${ }^{6}$ However, as described below, the security services in both countries were strong enough to engage in the type of repression under study and neither faced significant international pressure against deploying such repression. With these factors held constant, the comparative analysis of Georgia and Kazakhstan focuses attention on rulers' motives and the circumstances in which rulers would choose to engage in or abstain from harsh repression.

\section{Repression and the Coercive State}

This article examines how governments respond to the founding of opposition parties and movements by capitalist elites. Rulers in Georgia and Kazakhstan faced this similar decision point at the same time. After market reforms, wealthy businessmen and senior policymakers in both countries mobilized to challenge the political status quo. ${ }^{7}$ In Georgia, the capitalist opposition included Industry Will Save Georgia and the New Rights party, established in 1999 and 2001 respectively, by business elites who had made fortunes in the new market economy. They were joined by Western-educated and reform-minded politicians and economists, who 
defected from Shevardnadze's government to form the United National Movement in 2001 and the Burjanadze-Democrats in 2003. In Kazakhstan, the Republican People's Party of Kazakhstan (RNPK) was organized in 1998 led by Akezhan Kazhegeldin, a wealthy entrepreneur and former Prime Minister. In 2001, the country's most prominent businessmen and government officials mobilized to found the Democratic Choice of Kazakhstan (DCK) movement.

The nature of these opposition groups was similar across the two cases. At inception, these were elite-led organizations composed of wealthy entrepreneurs, former policymakers, and technocratic elites. They put forth similar platforms based on political and economic reforms, including strengthening political institutions, protecting property rights, and enacting marketfriendly policies. These movements also operated in similar socioeconomic contexts. Opposition groups are more likely to attract popular support within highly unequal societies, during economic recession, or when citizens are highly taxed. In 1995-2003, Georgia and Kazakhstan shared similar levels of inequality, economic growth, and taxation. ${ }^{8}$

Faced with this shared threat, rulers in Georgia and Kazakhstan responded with markedly different forms of political repression, defined as the state's use of coercive actions against political opponents, undertaken for the purpose of "imposing a cost on the target as well as deterring specific activities and/or beliefs perceived to be challenging to government personnel, practices or institutions." ${ }^{, 9}$ I particularly focus on the coercive measures taken against individual party leaders, as they play a crucial role in coordinating popular discontent and overcoming the barriers to collective action in non-democratic regimes. This is especially true in post-Soviet Eurasia, where political organizations are highly personalized, and mass mobilization is more often elite-led than grassroots-driven. In such circumstances, targeting repression to opposition leaders is an effective means of suppressing such groups at minimal cost, especially when 
undertaken in the early stages of a group's formation. ${ }^{10}$

In Georgia, the state pursued relatively mild repression. Opposition leaders were subject to sharp criticism and isolated legal harassment, but they did not suffer systematic violence, sustained prosecution, and or long-term imprisonment. The Georgian president issued public rebukes of his capitalist opponents-suggesting, for example, that they had "peculiar morals"; that their political activities were "anti-constitutional"; and that they represented "another attempt to sow destabilization." 11 Tax inspectors launched a brief investigation into one opposition leader. Yet, these efforts were limited. The security services did not use violence against opposition activists, nor did prosecutors seek to imprison them. The Ministry of Justice legally registered each of these parties.

In Kazakhstan, however, the state responded much more forcefully. Authorities pursued severe repression, which involved systematic and aggressive coercive actions - such as violent assaults, prolonged criminal prosecution, and lengthy prison sentences - that produced serious long-term consequences for the victim. Prosecutors in Kazakhstan charged opposition leader Akezhan Kazhegeldin with a misdemeanor offense for attending the meeting of an unregistered organization - thereby barring him from competing in national elections. Tax authorities also launched a far-reaching investigation into his business dealings, culminating in a conviction and ten year prison sentence for tax evasion and money laundering. Other RNPK leaders were victims of violent attack. By 2001, the party had all but dissolved as leaders resigned their positions, citing "weariness with the official harassment."12 DCK leaders faced similar consequences. Individual members were arrested on politically motivated charges; several spent time in prison. Two party leaders were later killed. ${ }^{13}$ As an organization, the DCK had difficulty 
registering with the Ministry of Justice and was eventually banned for posing a threat to national security.

What might explain this difference? One possible explanation lies in the sheer coercive strength of the state: perhaps Georgia's government lacked the capacity to repress as rigorously as Kazakhstan's government did. This hypothesis is plausible at first glance: Georgia experienced a civil war that fractured the coherence of the state in the early 1990s, while Kazakhstan did not. However, after assuming executive office in 1992, Shevardnadze unified the Georgian state and rebuilt the coercive apparatus. He co-opted the civil war-era militias into the security services and systematically purged the warlords from their positions of power. ${ }^{14}$ Moreover, most employees in the security sector were holdovers from the Soviet period. Shevardnadze previously served as Minister of Internal Affairs and maintained long-standing personal ties to the ministry: "when he came back to power in the new system, his comrades were still there. He had informal contacts with people within the ministry so he could keep better control." ${ }^{15}$ Finally, he constructed a system in which corruption incentivized state officials' to defend the status quo. Positions within Georgia's repressive agencies-including the police, security services, tax inspectorate, and judiciary - were extremely lucrative and highly coveted, because they afforded privileged access to illegal revenue streams. In short, within the coercive apparatus "every part of the system was interested in keeping the system working" by repressing serious challenges to the regime. ${ }^{16}$

A second alternative explanation might trace this outcome to differences in each state's risk of sanctions from the international community. Yet neither country faced particularly sharp international rebuke for conducting repressive strategies internally. The region's natural resources provided both regimes with leverage against foreign pressure. Kazakhstan directly 
controls massive oil and gas reserves, while Georgia holds strategic importance as a transport corridor for these resources. Consequently, the West softened its criticism of both governments. $^{17}$

In short, Shevardnadze and Nazarbayev both possessed the capacity and the autonomy to pursue known opposition activists. I suggest that what varied between these two cases was the rulers' will to repress, rooted in their shared kleptocratic nature but divergent sources of illegal wealth.

\section{A Theory of Kleptocracy}

Kleptocratic regimes are those autocracies in which the ruler and his inner circle of advisers - collectively referred to here as "ruling elites"- exploit public office to illegally enrich themselves and their families. Kleptocratic regimes may be identified according to three criteria. They are (1) personalist regimes with (2) high levels of corruption where (3) ruling elites have amassed a large private fortune while in office. Within the larger category of autocracy, personalist regimes are constructed around the individual ruler; other political institutions such as the military and ruling party do not exercise independent decision-making power. ${ }^{18}$ The circle of ruling elites in such regimes typically extends to cabinet ministers, deputy ministers, special advisers, and important regional governors. With the permission of the ruler, these top officials may be allowed to enrich themselves. Operationally, I use the Geddes-Wright-Frantz dataset to identify personalist autocracies. I measure corruption using the Transparency International Corruption Perceptions Index (CPI). States rated less than 3.0 within the ten-point index are

considered highly corrupt. ${ }^{19}$ I draw on global corruption NGOs, investigative reports, and international news media to assess rulers' wealth accumulation. 
Based on these measures, there were 32 kleptocracies in the world in 2000-2010, accounting for over one-third of all autocracies in existence at that time.

Table 1: Cases of Kleptocracy in 2000-2010

\begin{tabular}{|l|l|l|l|l|}
\hline \multicolumn{1}{|c|}{$\begin{array}{c}\text { Post-Communist } \\
\text { Eurasia }\end{array}$} & \multicolumn{1}{|c|}{ Africa } & \multicolumn{1}{c|}{ Asia } & \multicolumn{1}{c|}{ Middle East } & \multicolumn{1}{c|}{ America } \\
\hline Armenia & Cameroon & Afghanistan & Iraq (until 2003) & Haiti (until 2004) \\
Azerbaijan & Central African Rep. & North Korea & Libya & Vyria \\
Belarus & Chad & & \\
Georgia (until 2003) & Congo-Brazzaville & & & \\
Kazakhstan & Congo-Zaire & & \\
Kyrgyzstan & Gabon & & \\
Russia & Guinea & & \\
Serbia (until 2000) & Ivory Coast & & \\
Tajikistan & Liberia (until 2003) & & & \\
Turkmenistan & Mauritania (until 2005) & & & \\
Uzbekistan & Sudan & & & \\
& Togo & & & \\
& Uganda & & & \\
\hline
\end{tabular}

Across the category of kleptocracy, however, lies significant variation in the sources of rulers' illegal fortunes. Some kleptocrats extract bribe revenue from their own citizens. Ruling elites can extract illegal rents directly, by demanding informal payments from wealthy entrepreneurs in exchange for privileged access to state contracts, relief on commercial taxes, or permission to conduct business activity. They also may benefit indirectly. State officials at lower levels of government often collect bribes from smaller businesses, the aggregate profits of which accrue to ruling elites indirectly through profit-sharing "corruption pyramids." In both instances, domestic society serves as the source of rulers' illegal wealth.

In contrast, other kleptocrats build their illegal fortunes on private payments from foreign actors. This is particularly common in those resource-rich countries where kleptocratic rulers exert de facto control over the country's hydrocarbon and mineral deposits. Resource-rich kleptocrats can extract bribes from multinational oil companies - in addition to the official purchase price - in exchange for granting ownership, exploration, or extraction rights. ${ }^{20}$ Such bribes are front-loaded at first; the payment is completed before initial contracts are signed. But 
shrewd kleptocrats can threaten to renegotiate these contracts at regular intervals, effectively converting upfront bribes into an ongoing source of revenue. ${ }^{21}$

I contend that this distinction between domestic versus foreign sources of bribe revenue creates diverging incentives when it comes to dealing with the capitalist opposition. The causal mechanism that I propose focuses on the extent to which these leaders perceive domestic economic growth to be key to their ability to extract private rents.

Kleptocratic rulers seek to maximize their long-term personal profit through the continued accumulation of illegal wealth. But, much like Mancur Olson's metaphor of the stationary bandit, society-reliant kleptocrats reap the greatest long-term profits through continued growth in the domestic economy. It is in society-reliant kleptocrats' interest to protect citizens - especially those who generate considerable economic growth - in order to engage in ongoing revenue extraction. Over the long run, these rulers will be able to accumulate greater aggregate wealth through bribes and kickbacks if they leave citizens with incentives to continue engaging in revenue-generating activities. This includes refraining from harsh repression: "since all of the settled bandit's victims are for him a source of tax payments, he also has an incentive to prohibit the murder or maiming of his subjects." 22

These incentives become particularly acute when leaders of the major opposition groups are private businessmen or former government officials. Parties of the economic elite have financial resources and insider knowledge to credibly challenge the regime. But for those rulers who extract their fortunes from domestic citizens, the leaders of these parties are also a critical source of illegal rents. As managers of the country's most profitable businesses, entrepreneurial elites typically pay the biggest bribes. Their companies also serve as major employers and the engines of economic growth. Similarly, former policymakers have technical expertise that a 
kleptocrat needs, especially if they were previously involved in formulating economic policy or market-supporting institutions. Severe repression is thus likely to cut into society-reliant kleptocrats' long-term bribe revenue. Citizens who are dead or in prison cannot contribute to the economy; the opportunity costs are higher when those citizens have specialized knowledge and experience. Fear of aggressive repression also raises the possibility of brain drain and capital flight. Capitalist opponents under threat are likely to liquidate their companies, move their business investments offshore, and flee abroad. Society-reliant kleptocrats are financially better off if they keep these businessmen and technocrats safe and invested in the domestic economy, regardless of their political activities. ${ }^{23}$

In contrast, resource-rich kleptocrats have less concern for long-term domestic economic growth. With access to foreign bribes, they can accrue illegal wealth regardless of how the domestic economy performs. Such rulers face incentives more similar to Olson's roving bandit, who behaves with little regard for the future productivity of society. Moreover, while domestic capital is likely to flee repression, foreign capital will not. ${ }^{24}$ In the pursuit of extraordinary profits, foreign companies, especially in the resource sector, are likely to continue investing in resource-rich economies despite state-sponsored violence. Thus, resource-rich kleptocrats can repress even wealthy economic elites without jeopardizing their accumulation of illegal rents. ${ }^{25}$

The argument is summarized in Figure 1. By this logic, the revenue-maximizing intensity of repression will vary between these two types of kleptocrats. Rulers who build their fortunes on bribes from society will pursue lower intensity repression compared with rulers who collect bribes from external sources. 
Figure 1: The Argument

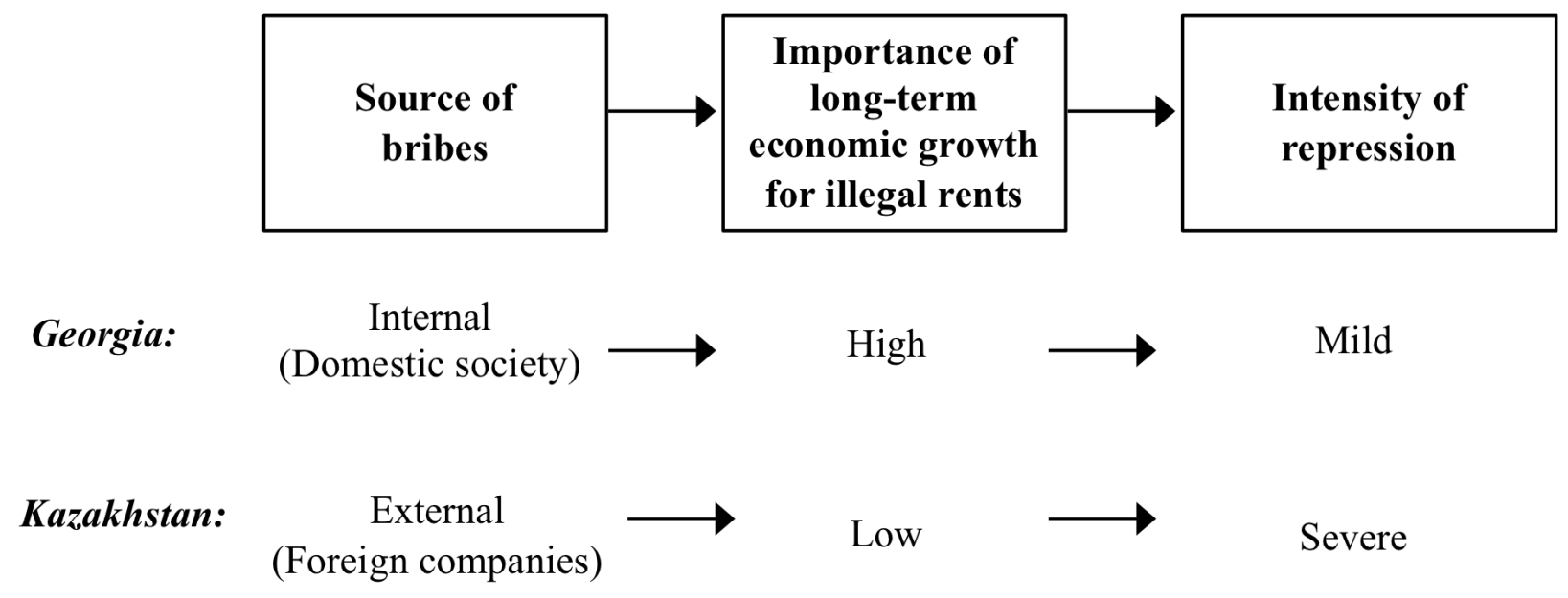

The influence of illegal revenue streams on the treatment of capitalist opposition can be seen through the contrasting cases of Georgia under President Eduard Shevardnadze and Kazakhstan under President Nursultan Nazarbayev. Both regimes qualify as kleptocratic between 1995 and $2003 .^{26}$ Corruption was pervasive in each, with average CPI scores of 2.1 (in Georgia) and 2.4 (in Kazakhstan) for these years. Significant evidence suggests that ruling elites used their positions to extract huge private fortunes. But the source of their illegal fortunes varied, creating divergent willingness to aggressively repress the capitalist opposition.

\section{Domestic Bribes and Mild Repression in Georgia}

\section{Source of Bribes: Domestic Society}

Within Georgia's kleptocracy, ruling elites relied on domestic society for their illicit income. Georgia's natural resource endowment is negligible. ${ }^{27}$ Instead, Shevardnadze's family and top government officials extracted their illegal fortunes from private citizens. By the early 2000s, Georgia had the highest levels of domestic bribery of all the post-Soviet countries. 
Experts estimate that the amount of bribes collected annually by Georgian officials totalled between $\$ 75$ and $\$ 105$ million-nearly 20 percent of government income. ${ }^{28}$

Ultimately, the profits of these corruption pyramids accumulated to cabinet ministers and to the Shevardnadze family. ${ }^{29}$ The president's family reaped the greatest benefits. The Shevardnadze family oversaw "all large-scale business in Georgia" and derived their wealth from "embezzlement, contract-fixing and colossal bribes." ${ }^{30}$ As one analyst noted, "if one wants to establish a big business in Georgia, he needs to find a common language with the family of the President." ${ }^{31}$ Wealth accumulation within the Shevardnadze family was concentrated among three main clans. The first, led by Shevardnadze's nephew, Nugzar Shevardnadze, benefited from the import of consumer goods. Shevardnadze's son-in-law, Gia Jokhtaberidze, headed a second group that was active in telecommunications. The third group, led by Guram Akhvlediani, controlled shipping through the port of Poti. ${ }^{32}$

Shevardnadze actively protected his family's accumulation of illegal wealth, though there is little evidence that he demanded bribes himself. Internal government memos from the period demonstrate that he maintained up-to-date knowledge about his family members' illegal business dealings and worked to forestall any interruption to their revenue streams. Investigative journalists who exposed corruption within the Shevardnadze family routinely received angry phone calls and harassment from the president's wife. ${ }^{33}$ In public statements, Shevardnadze also refused to act against the family's self-enrichment, commenting: "as regards relatives suspected of involvement in corruption, I have already said that there is no country whose president can control his relatives, especially if the president has a wide circle of relatives. This is practically impossible." 34 As one analyst noted, "the illegal business activity of the Presidential environment represented an interest of Shevardnadze himself., 35 
Beyond the Shevardnadze family, the extraction of bribes transcended different sectors of the economy and spheres of influence within government. Within each sector of the economy, high-level government officials acted as patrons to "protect" the markets within their jurisdiction. For example, the Economic Minister controlled export licensing: "If someone wanted to export scrap metal, he paid thousands of dollars to the minister of the economy. The size of the bribe depended on the volume of the export. ${ }^{\not 36}$ Moreover, within each ministry, state officials who collected bribes were required to share a portion of their bribe revenue with their superiors. This process was pervasive: 64 percent of public officials admitted to passing on a portion of their bribe revenue to their supervisors. ${ }^{37}$ It was also institutionalized: for example, within the Ministry of Internal Affairs, each person could keep one-third of the bribe profits and transfer two-thirds of the money to his superior. ${ }^{38}$ This process of sharing illegal revenue repeated itself up the administrative hierarchy, with profits becoming consecutively larger as they aggregated upwards to ruling elites. In addition to sector-specific patrons, entrepreneurs were extorted for illegal payments by the tax and regulatory agencies; businesses paid bribes to avoid formal taxation or to reduce the size of their bills. ${ }^{39}$

Criminal prosecutions pursued after Shevardnadze's ouster in the 2003 Rose Revolution hint at corruption's prevalence. Shevardnadze's son-in-law, Gia Jokhtaberidze, paid $\$ 15.5$ million to prosecutors to avoid charges of tax evasion. Sulkhan Molashvili, who served as Chief Auditor and headed the government's anti-corruption council, was charged with misappropriating millions and coordinating the Shevardnadze family's illegal revenue streams. Other Shevardnadze-era officials charged with major financial crimes included Davit Mirtskhulava, energy minister; Alexander Kartozia, education minister; Vladimir Sanadze, deputy education minister; Merab Adeishvili, Transport and Communications minister; Akaki 
Chkhaidze, chief of national railway; David Kirvalidze, Minister of Agriculture; Davit Shervashidze and Khuta Mamaladze, deputy ministers of agriculture; Shota Meparidze, chief of forestry; Valerie Vashakidze, Minister of Refugees and Accommodation. ${ }^{40}$

\section{Shevardnadze's Political Opponents}

The reliance on domestic society for bribes made Shevardnadze and his advisers reluctant to crack down on wealthy opponents. Business elites who had made fortunes in the new market economy began to organize politically in the late 1990s. The party Industry Will Save Georgia was established in 1999 to lobby for the protection of the Georgian manufacturing sector. The New Rights party was established in June 2001, when several businessmen elected to parliament in 1999 defected from the ruling party. A second wave of capitalist opposition arose from the "young reformers" wing of the ruling Citizens United Georgia (CUG) party. The first to defect was the Minister of Justice Mikheil Saakashvili, who announced the founding of his opposition party, the United National Movement, in October 2001. The speaker of parliament, Zurab Zhvania, resigned from government the following month. They were joined by Nino Burjanadze. In 2003, Burjanadze and Zhvania allied to form the opposition Burjanadze-Democrats.

The leaders of these parties were engaged in more than just political activities. They also were the country's leading economists and owners of the most profitable companies. Through their financial holdings and economic expertise, opposition leaders played an important role in generating economic growth, and thus providing illegal revenue for government officials.

Parties of the Business Elites: The founders of "Industry Will Save Georgia" and "New Rights" were some of the most successful entrepreneurs in Georgia. Between 1995 and 2003, Georgia's economy grew an average of $6 \%$ annually, achieved largely through growth in the industrial and service sectors. ${ }^{41}$ The politicians of the new business elite had deep connections in 
those sectors - and in some cases, headed the individual companies - that were responsible for much of this growth. The Industrialist party was headed by Gogi Topadze, owner of Kazbegi Brewery, while New Rights was co-founded by Levan Gachechiladze, owner of Georgian Wine and Spirits. New Rights also gained endorsement from President of the TBC banking group, Mamuka Khazaradze. TBC was among the leading financial institutions in Georgia at the time and operated the Borjomi mineral water company. These enterprises together constituted a major portion of Georgia's beverage industry, which in turn made up five percent of GDP and the largest single share of manufacturing outputs during this period. As one expert suggested, beverage production represented "the greatest single exception to the generally dire situation of Georgian industry."42 The second co-founder of New Rights was David Gamkrelidze, founder of Aldagi, Georgia's largest insurance company. In 1994, the company was granted a sectoral monopoly; Aldagi became the sole insurer of private vehicles and the transit of commercial goods in Georgia. ${ }^{43}$

These were the sorts of profitable enterprises within the formal economy that government officials extorted for large bribes. Bribes were a necessary part of doing business in Georgia. In 2002, 74.2 percent of commercial enterprises reported that they were expected to make informal payments to public officials in order to "get things done."44 The size of a bribe was calculated as a proportion of the company's revenue; more profitable enterprises were extorted for bigger payments. Thus, tax collectors routinely waived companies' tax bills in exchange for a bribe of 30 percent of the amount owed. ${ }^{45}$ With very profitable companies, bribes were formalized as profit-sharing schemes. For example, Aldagi allegedly secured its insurance monopoly through ongoing kickbacks to the Minister of Internal Affairs. ${ }^{46}$

New Reformers: The new reformers played different role in the generation of bribe 
revenue for Shevardnadze's government. They were not entrepreneurs. Rather, they were the country's specialists on market capitalism and rule of law. These young, Western-educated technocrats were experts on how to create market economies, secure property rights, and foster long-term macroeconomic growth. Before going into opposition, Mikhail Saakashvili served as Georgia's Minister of Justice, having trained in the U.S. at Columbia Law School and George Washington University School of Law. In the 1990s, he was chairman of the parliamentary committee that oversaw the creation of a new electoral system and independent judiciary. Nino Burjanadze held a doctorate in international law and had spearheaded several parliamentary committees on constitutional reform and foreign relations. The group also included economic experts, such Mikheil Machavariani, former Minister for Taxes and Revenues, and Zurab Noghaideli, former Minister of Finance.

These technocrats held the macroeconomic and legal expertise on which Georgia's longterm growth depended, and which was in short supply across the post-Soviet region during the 1990s and early 2000s.

\section{Linking Illegal Wealth and Repression}

Because Georgia's ruling elites depended on illicit payments extracted from society, they were not willing to undertake the risks of repressing capitalist opponents. Shevardnadze responded to the founding of capitalist opposition parties with nasty comments and public criticism. Tax authorities launched an audit into the business records of Gogi Topadze, founder of Industry Will Save Georgia. The Supreme Court ordered him to pay 3 million dollars in overdue taxes - a charge which he publicly disputed. ${ }^{47}$ Authorities also put financial and legal pressure on media outlets associated with the opposition. But the government did not physically harass, violently attack, or seriously prosecute the leaders of the opposition. The Georgian 
government's laissez-faire approach was captured by Shevardnadze's response when asked about the movement of business elites into opposition politics. Shevardnadze replied simply: "Let it be on their conscience." ${ }^{, 48}$

The light repressive tactics aimed at the capitalist opposition contrasts with the government's treatment of other, more marginal opposition groups that did not generate significant bribe revenue. The Zviadist movement—who supported Shevardnadze's deposed predecessor, Zviad Gamsakhurdia-was composed of poor citizens, with few assets or specialized knowledge. Despite their frequent attempts, they were not allowed to register, their protest attempts were consistently dispersed, and they were banned from contesting elections. ${ }^{49}$ Because they challenged to the regime but were not economically profitable, they faced more severe repression.

Shevardnadze over various occasions outlined the logic of the stationary bandithighlighting the importance of entrepreneurs for economic growth and tax collection, while also reassuring them that they and their investments were safe in Georgia. Although Georgian politicians readily acknowledged the pervasiveness of corruption among state officials, highranking officials rarely admitted to engaging in rent-seeking behavior themselves. While governing officials did not explicitly link their mild repressive response to their desire to reap illegal wealth, they did articulate a strong economic interest in keeping business elites — and their associated capital and expertise — invested within Georgia, despite their political activity.

Many of Shevardnadze's statements focused on the role of entrepreneurs in maximizing official state revenue. In a 2001 speech, he noted, "Georgia's state budget is made of hundreds of millions of dollars. Where does the cash come from? .... the treasury gets cash mainly from the wealth built through private initiative in private enterprises and private businesses." He further 
exhorted wealthy Georgian entrepreneurs, regardless of political affiliation, to "invest his profit in immovable property, build houses, if he wishes, create some other wealth and so on. A normal businessman will, indeed, invest the major portion of his income back into business and try to expand his enterprise, thus enriching the public wealth." ${ }^{50}$ Taken at face value, these comments convey concern about the official budget. But in context of the impressive rate at which public officials converted tax bills into personal bribes, they also suggest an interest in generating illegal private profits.

Shevardnadze also emphasized that any anti-corruption efforts would not come at the expense of existing property rights or the well-being of wealthy entrepreneurs: "I will not permit the fight against corruption to turn into, as they say, witch-hunting, an excuse to violate human rights, or a brake impeding the development of businesses and the banking system." ${ }^{51}$ On another occasion, he reiterated, "The fight against corruption should not grow into social vengeance. We must refrain from promoting [a] social feud. ${ }^{, 52}$ Although the Georgian government was under strong pressure from international donors to fight graft, Shevardnadze affirmed that he had little intention of disrupting the status quo.

\section{Foreign Bribes and Severe Repression in Kazakhstan}

\section{Source of Bribes: Foreign Companies}

In Kazakhstan, ruling elites had access to informal payments from foreign companies, yielding a very different set of incentives. Domestic bribery existed in Kazakhstan: a majority of firms during this period reported that they made informal payments to public officials. ${ }^{53}$ Yet the large informal payments made by foreign companies, who sought access to the country's immense hydrocarbon deposits, overshadowed domestic bribery. 
Kazakhstan's territory is rich with oil and gas. Under Soviet rule, rights to the republic's oil and gas fields were held by the central government in Moscow. By the 1980s, the Kazakh republic produced between seven and nine percent of Soviet oil production, ranking it second among the republics behind Russia. ${ }^{54}$ Today, the country's oil and gas fields include the some of the biggest in the world: oil reserves exceed 30 billion barrels and its gas reserves total 85 trillion cubic feet. The Kashagan field, discovered in 2000, is the largest oil field outside the Middle East. The Tengiz field is the world's sixth largest oil field. The Karachaganak field is among the world's largest deposits of gas condensate. ${ }^{55}$

With the dissolution of the USSR, the rights and management of these resources transferred to the newly sovereign state of Kazakhstan. The government pursued an aggressive plan to sell off ownership and development rights to foreign-owned companies. Two transactions have come under particular scrutiny. The first, concluded in 1993, established TengizChevroil, a joint venture between Chevron and the Kazakh state oil company with exclusive rights to develop and operate the Tengiz field. In the second deal, in April 1996, the government sold half of its shares in TengizChevroil to Mobil for approximately $\$ 1$ billion. Further ownership and production-sharing deals, also worth billions of dollars, were concluded with foreign consortia in subsequent years. ${ }^{56}$

Foreign court proceedings and investigative journalism shed light on how Nazarbayev and his inner circle used their control over these oil and gas fields to enrich themselves. Many early deals were brokered by James Giffen, an American merchant banker hired to advise the Kazakh government on oil sector development. In a 2003 indictment, US prosecutors alleged that Giffen passed a total of $\$ 78$ million in bribes from foreign companies to Nazarbayev and then-Minister of Oil, Nurlan Balgimbayev. ${ }^{57}$ Oil companies seeking to do business in 
Kazakhstan were asked to cover the fees incurred by the Kazakh government to Giffen's company. Giffen then skimmed money from those payments and dispersed kickbacks to Nazarbayev and Balgimbayev. In other cases, Giffen instructed oil companies to deposit payments into escrow accounts at Swiss banks, which in turn were diverted into private accounts associated with Giffen, Nazarbayev, and Balgimbayev.

Mobil Oil's 1996 buy-in to the Tengiz field is illustrative of this dynamic. In the fall of 1995, during discussions over Mobil's potential buy-in, Nazarbayey reportedly demanded that the company buy him a new Gulfstream jet, provide funds for tennis courts to be built at his home, and donate several trucks with satellite dishes to his daughter's television network. Mobil officials did not comply. ${ }^{58}$ But the company made a $\$ 5$ million "goodwill payment" to Giffen's company to secure exclusive rights to buy into Tengiz. Mobil also granted an unsecured loan to an assetless shell company from which $\$ 1$ million was diverted to Balgimbayev's private account. In total, between August 1995 and May 1996, Mobil paid Giffen a total of \$51 million in fees to his Citibank account in New York-more than half of which was passed on to private accounts held by Nazarbayev and Balgimbayev. Giffen also used these accounts to pay $\$ 36,000$ towards the maintenance of Balgimbayev's family home in Massachusetts; to purchase $\$ 30,000$ in fur coats for Nazarbayev's wife and daughter; to buy a speedboat for Nazarbayev; and to cover $\$ 45,000$ in Swiss boarding school tuition for Nazarbayev's daughter. ${ }^{59}$

Other members of Nazarbayev's inner circle have been implicated in these kickbacks as well. In 2007, the American company Baker Hughes confessed to paying a total of $\$ 5.2$ million in bribes to unnamed executives at KazakhOil, the state oil company, in order to secure oil services contracts. ${ }^{60}$ Separately, Timur Kulibayev, the president's son-in-law and a major figure in Kazakhstan's oil and gas industry, was investigated for his role in the sale of state 
hydrocarbon assets to a Chinese oil company. Kulibayev was accused of taking a \$166 million bribe from CNPC in exchange for selling at a reduced price a large stake in AktobeMunaigas, Kazakhstan's fourth largest oil producer. Legal investigations were conducted in both Kazakhstan and Switzerland, though charges were dropped in both countries. Nonetheless, Wikileaks releases capture concerns articulated by a senior official at the state oil company over what that official dubbed Kulibayev's "avarice for large bribes" from foreign enterprises. ${ }^{61}$

\section{Nazarbayev's Political Opponents}

Kazakhstan's rulers did not need domestic economic growth for their illegal wealth, and so were increasingly willing to face the economic consequences of repressing capitalist opponents. In Kazakhstan, two capitalist opposition parties were founded in 1995-2003. The first was the Republican People's Party (RNPK), established in 1998 and led by Akezhan Kazhegeldin, a wealthy entrepreneur and former Prime Minister. In 2001, a second opposition party emerged with the creation of the Democratic Choice of Kazakhstan (DCK). The DCK movement was established in November 2001 by a group of prominent businessmen and senior government officials.

As in Georgia, the leaders of these opposition parties were among the country's biggest entrepreneurs, most forward-thinking technocrats, and leading experts on market reforms. The RNPK's founder Kazhegeldin was one of Kazakhstan's leading industrialists and the architect of Kazakhstan's post-Soviet economy. Trained as an economist, Kazhegeldin served as an enterprise manager in Kazakhstan's industrial north before co-founding the Semei industrial conglomerate, one of the earliest commercial enterprises in Kazakhstan. As Prime Minister, he implemented sweeping reforms, including privatization of small and medium enterprises and construction of market-supporting institutions. The government also founded Kazakhstan's stock 
exchange and pioneered management contracts to bring investment into the largest factories during his tenure. ${ }^{62}$ These reforms had far-reaching effects. The share of small firms in private hands rose from 27.3 percent in 1993 to 100 percent in 1997. The private sector's contribution to GDP increased from 10 percent to 55 percent over the same time period. ${ }^{63}$ And in these early years of economic restructuring, "tens of millions of dollars were invested in Kazakhstan that might otherwise have been withheld, as a result of the management contracts pioneered by Kazhegeldin's government.",64

The founding members of DCK were directors of Kazakhstan's largest commercial banks and biggest financial industrial conglomerates. Mukhtar Ablyazov owned Turan-Alem (later BTA) Bank, among many other assets, through his massive Astana-Holding company. He also served as chair of Temir Bank and Minister of Power, Industry, and Trade. Nurzhan Subkhanberdrin was director of Kazkommertsbank. A third DCK signatory, Bulat Abilov, founded Butya-Kapital, an investment firm that had been "the largest single actor" in the purchase of state-run enterprises. ${ }^{65}$ Other DCK signatories included Galymzhan Zhakiyanov, managing director of Semei industrial group; Tolegen Tokhtasynov, head of Alel financial investment firm; and Nurlan Smagulov, founder and president of Astana Motors, the country's main manufacturer and importer of cars. ${ }^{66}$

These entrepreneurs were joined by senior government officials and influential economists. Oraz Dzhandosov was Minister of Finance and former head of the National Bank of Kazakhstan. He directed the country's macroeconomic strategy, including relations with international financial institutions. Kairat Kelimbetov was Dzhandosov's deputy; he had drafted Kazakhstan's official ten-year plan for economic development. Alikhan Baymenov was Minister of Labor and Social Protection. Previously, as head of Kazahstan's civil service, he had enacted 
far-reaching bureaucratic reforms, including competitive selection for administrative posts and meritocratic promotion procedures. Others were regional governors. Zamanbek Nurkadilov was governor of the country's financial capital Almaty. Galimzhan Zhakiyanov served as governor of Semipalatinsk and, later, Pavlodar. During his tenure, the regions "became a testing ground for social and economic reforms."

If Nazarbayev and his inner circle had relied on domestically sourced bribes, these opposition figures - as bankers, industrialists and economic policymakers - would have been critical for rulers' continued accumulation of illicit wealth through production and growth. ${ }^{68}$ One newspaper editorial noted the unique value of the DCK organizers, stating: "against the backdrop of the remaining 'swamp"' of Kazakhstan's elite, the DCK founders were "intelligent, eloquent and principled. ${ }^{\circ 9}$ Nazarbayev acknowledged as much. When reappointing Oraz Dzhandosov as Finance Minister in 2000, Nazarbayev promised that Dzhandosov would "ensure the stability of the country's economic development and maintain the tempo of economic growth." He added that Dzhandosov was "the most well-prepared of Kazakhstan's economists, is well-known in international financial institutions, a reformer by nature who knows what he wants.",70

\section{Linking Illegal Wealth and Repression}

But Kazakhstan's kleptocrats faced different incentives with regard to the opposition. Ruling elites did not depend on domestic economic growth for their illegal wealth, and so were willing to aggressively repress wealthy opponents. RNPK leaders faced violent assaults and criminal prosecution. Several RNPK leaders were physically attacked-including the party's press spokesman, its public relations adviser, and a party representative who was nearly killed. Tax authorities launched a multi-year investigation into Kazhegeldin's financial affairs. Kazhegeldin fled abroad in 1998; at the time of his trial, he does not appear to have remaining 
financial investments in Kazakhstan. ${ }^{71}$ He was found guilty of corruption-related charges and sentenced in abstentia to ten years in prison.

After DCK was established in 2001, Nazarbayev made it clear that his first priority was suppressing the capitalist opposition, and that he was willing to risk brain drain and capital flight to achieve this objective. He publicly warned that economic elites-as well as their associated investments and expertise-were welcome in Kazakhstan only up to a point. Nazarbayev announced, "We need them [entrepreneurs] — both large businesses and especially small and medium-sized businesses... but they should not interfere either directly or indirectly, through their people in power, in taking political decisions." ${ }^{, 2}$ At another point, the president actively encouraged opposition leaders to leave the country. In a loosely veiled reference to the DCK, Nazarbayev declared, "All those who say everything is bad and that we have corruption, that we have this and that, only cheat Kazakh citizens. We should get rid of them. Let them go to Kyrgyzstan... Is it clear?"73

DCK leaders' safety became contingent on abstaining from opposition politics. Those entrepreneurs who renounced the DCK were rewarded. Just days after Nazarbayev's public ultimatum, Yerzhan Tatishev, a DCK leader and chairman of BTA Bank, issued a public statement abandoning politics: "the very decision to join [DCK] was originally taken by all banks somewhat spontaneously. Taking part directly or indirectly, through managers, in various political movements is not correct with respect to the professional form of business."74 Nurzhan Subkhanberdin also resigned from DCK and retained control of Kazkommertsbank. Kairat Kalimbetov quickly removed himself from political debates; he was subsequently appointed Minister of Economic and Budget Planning. ${ }^{75}$ 
Those who did not exit opposition politics faced systematic repression. Bulat Abilov was investigated for embezzlement and tax evasion. In 2004, he was charged with criminal libel and fined $\$ 38,000$ for insulting a member of parliament. In 2002, Galimzhan Zhakiyanov was sentenced to seven years in prison for embezzlement and abuse of office during his time as governor of the Pavlodar region. He was pardoned and released in February 2006. Mukhtar Ablyazov was sentenced to six years in jail on similar charges; he was pardoned in 2004. For Ablyazov and Zhakiyanov, staying out of politics was a condition of their release. ${ }^{76}$

DCK leaders responded to this political repression by liquidating their companies, moving their business investments offshore, and fleeing abroad. Abilov dissolved his investment fund, Butya-Kapital in December 2004. In an open letter to shareholders, he said that his decision was motivated by the fact that the government was putting pressure on his business, as a result of his political activities. ${ }^{77}$ Ablyazov moved to Moscow after his release in 2003 and invested millions of dollars in British real estate assets. ${ }^{78}$ Zhakiyanov relocated to the United States and redirected his financial investments to China and Mongolia. ${ }^{79}$

The DCK founders had publicly cautioned about the potential consequences of repression. This was articulated most explicitly by Bulat Abilov, who described the charges against Zhakiyanov and Ablyazov as "a real strike at both major and medium-sized businesses in Kazakhstan." He announced, "I know many businessmen who are now thinking of taking their businesses out of Kazakhstan. They believe that continuation of economic repression in relation to any businessman is possible... they are negotiating the sale of their companies here and have already started to work out ways of transferring their businesses to Russia." ${ }^{80}$ However, the government refused to change course. Nazarbayev responded by declining to intervene in the DCK trials, stating "The court will say whether they are criminals or not. Far be it for me to 
judge anybody." ${ }^{\prime 11}$ In a regime in which the judiciary is not independent from the executive, this refusal to stop the proceedings effectively green-lighted the oppositionists' conviction.

In other settings, the desire to extract bribe revenue might discourage rulers from repressing political opponents, especially those with considerable wealth or those who are key to growth and production. However, Kazakhstan's rulers accumulated personal wealth not from society but from the country's natural resources. As one person explained in my interviews, "the political elite got rich off of oil and privatization deals; there is little business otherwise." ${ }^{" 82}$ The source of kleptocratic accumulation thus shaped the extremely repressive approach that the government took towards political opposition.

\section{Conclusion}

The comparative analysis of Georgia and Kazakhstan suggests that, in kleptocratic regimes, the source of rulers' illegal revenue bears political consequences. In Georgia, where ruling elites amassed wealth from domestic entrepreneurs, regime figures faced a trade-off between promoting long-term growth and repressing their political opponents. Georgia's kleptocrats had to tolerate the capitalist opposition in an effort to encourage economic activity and thus maximize their revenue from bribes. Resource-rich rulers in Kazakhstan faced no such choice. They could pursue aggressive repression without jeopardizing their accumulation of private rents.

This theoretical framework sheds new light on broader patterns of corruption and government-opposition relations across post-Soviet Eurasia. In Russia, the regime has been described as a "corrupt autocracy" that "operates more as a kleptocracy than a government." Putin's government has centralized control over the natural resource sector, pursuing direct and 
indirect ownership over the resource sector, as well as bribes from the oligarchs, governors, and state officials who preside over the sector. ${ }^{84}$ Access to these illegal payments has enabled Kremlin officials to crack down against politically minded oligarchs. A similar story has played out in oil-rich Azerbaijan. By contrast, the resource-poor kleptocracies of Eurasia-including the governments of Kyrgyzstan and Armenia — have granted capitalist opponents significantly more leeway to organize. This variation suggests there is broader generalizability beyond the cases under consideration.

These insights also generate policy implications. The analysis of resource-rich kleptocracies implies that programs monitoring official resource revenues, such as the EITI, are necessary but insufficient for addressing corruption in the extractive industries. These programs will be only partially successful without corresponding measures to ensure transparency in the awarding of licenses and contracts. The study also calls attention to the need for programs, such as the Foreign Corrupt Practices Act in the US, to hold foreign bribe payers to account. More generally, the study of kleptocracies underscores the limitations of principal-agent models in the formulation of anti-corruption initiatives. Kleptocratic regimes are distinguished precisely by their lack of "principled principals." $" 85$ When rulers themselves are corrupt, anti-corruption reforms targeting lower-level agents are unlikely to alter these dynamics.

\footnotetext{
${ }^{1}$ In both Georgia and Kazakhstan, new constitutions were adopted in 1995 institutionalizing strong presidencies at the expense of the legislatures and judiciaries. The study ends for both countries in 2003 when Shevardnadze's

${ }^{2}$ Field research for this project was conducted in 2008 and 2009, with additional fieldwork in 2014.

${ }^{3}$ Susan Rose-Ackerman, Corruption and Government: Causes, Consequences, and Reform (New York: Cambridge University Press, 1999); Pranab Bardhan, "Corruption and Development: A Review of the Issues," Journal of Economic Literature, 35:3 (September 1997): 1320-1346; Daniel Gingerich, "Corruption and Political Decay: Evidence from Bolivia," Quarterly Journal of Political Science 4:1 (2009); Bo Rothstein, The Quality of Government: Corruption, Social Trust, and Inequality in International Perspective (Chicago: University of Chicago Press, 2011).

${ }^{4}$ Daron Acemoglu and James Robinson, Why Nations Fail (London: Profile Books, 2012), 430.

${ }^{5}$ For the former, see Rose-Ackerman, 1999; Bardhan, 1997. For the latter, see Keith Darden, "The Integrity of Corrupt States: Graft as an Informal State Institution," Politics \& Society 36:1 (March 2008); Hanne Fjelde and
} 
Havard Hegre, "Political Corruption and Institutional Stability," Studies in Comparative Institutional Development 49:3 (September 2014).

${ }^{6}$ Steven Levitsky and Lucan Way, Competitive Authoritarianism: Hybrid Regimes after the Cold War (New York: Cambridge University Press, 2010); Eva Bellin, "The Robustness of Authoritarianism in the Middle East:

Exceptionalism in Comparative Perspective," Comparative Politics 36:2 (January 2004); Lucan Way and Steven Levitsky, "The Dynamics of Autocratic Coercion after the Cold War," Communist and Post-Communist Studies 39 (2006); Milan Svolik, The Politics of Authoritarian Rule (New York: Cambridge University Press, 2012); Michael Albertus and Victor Menaldo, "Coercive Capacity and Prospects for Democratization," Comparative Politics 44:2 (January 2012).

7 Scott Radnitz, "The Color of Money: Privatization, Economic Dispersion, and the Post-Soviet 'Revolutions,", Comparative Politics 42:2 (January 2010); Barbara Junisbai, "Improbable but Potentially Pivotal Oppositions: Privatization, Capitalists, and Political Contestation in the Post-Soviet Autocracies," Perspectives on Politics 10:4 (December 2012); Henry Hale, Patronal Politics (New York: Cambridge University Press, 2015). Junisbai (2012) convincingly argues that some capitalists sought to protect their own business interests, which were under threat of expropriation by a subset of ruling elites. Her findings do not preclude the argument here. Just as Junisbai highlights that capitalists could decide how to respond to threatened expropriation, my argument rests on the point that these presidents had agency in choosing whether to repress capitalists' attempts at political mobilization.

${ }^{8}$ Daron Acemoglu and James Robinson, Economic Origins of Dictatorship and Democracy (New York: Cambridge University Press, 2006); Hazem Beblawi and Giacomo Luciani, eds., The Rentier State (London: Croom Helm, 1987); Michael Ross, “Does taxation lead to representation?” British Journal of Political Science 34:2 (April 2004). Average Gini scores were 40.9 (Georgia), 36.3 (Kazakhstan). Economic growth averaged 5.9\% (Georgia), 4.1\% (Kazakhstan). Average tax revenue was 7.5\% of GDP in Georgia; 9.6\% in Kazakhstan (World Bank, World Development Indicators).

${ }^{9}$ Christian Davenport, "State Repression and Political Order," Annual Review of Political Science, 10 (2007), p. 2.

${ }^{10}$ Vitali Silitski, "Preempting Democracy: The Case of Belarus," Journal of Democracy 16:4 (October 2005); Henry Hale, Why Not Parties in Russia (New York: Cambridge University Press, 2005); Scott Radnitz, Weapons of the Wealthy: Predatory Regimes and Elite-Led Protests in Central Asia (Ithaca: Cornell University Press, 2010). I thus investigate variation within what Way and Levitsky (2006) call "low intensity coercion."

11 "Georgia: Government-backed 'oligarchs' accused of plotting attacks on opposition,” Rustavi-2 TV, 20 May 2002; "Georgian president to lead new bloc to election victory," Georgian Radio, 7 April 2003

${ }^{12}$ Martha Brill Olcott, Kazakhstan: Unfulfilled Promise? Revised Edition (Washington: Carnegie Endowment, 2010): 123

${ }^{13}$ In November 2005, Nurkadilov was found dead at his home with multiple gunshot wounds. In February 2006 , Altynbek Sarsenbayev was kidnapped and killed along with his driver and bodyguard.

${ }^{14}$ By 1995, the warlords who invited him to power were dead, in prison, or in exile. Ghia Nodia, "Putting the State Back Together in Post-Soviet Georgia," in Crawford and Beissinger, eds., Beyond State Crisis? Postcolonial Africa and Post-Soviet Eurasia in Comparative Perspective (Washington: Woodrow Wilson Center Press, 2002).

${ }^{15}$ Personal interview with Georgian security expert, Tbilisi, March 2009; see also Jonathan Wheatley, Georgia from National Awakening to Rose Revolution (Burlington VT: Ashgate, 2005), pp. 87, 113.

${ }^{16}$ Personal interview with Georgian security expert, Tbilisi, March 2009. For a similar perspective, see Johan Engvall, "Why are public offices sold in Kyrgyzstan?" Post-Soviet Affairs 31:1 (2014).

${ }^{17}$ Lincoln Mitchell, “Georgia’s Rose Revolution,” Current History 103: 675 (October 2004), 342-348.

${ }^{18}$ Barbara Geddes "What do we know about democratization after twenty years?" Annual Review of Political Science 2:1 (1999), 115-144.

${ }^{19}$ Darden, 39.

${ }^{20}$ Not all resource-rich rulers have de facto personal control over the country's resources, nor do all such rulers sell their resource assets to foreign investors. Pauline Jones Luong and Erika Weinthal, Oil is Not a Curse (New York: Cambridge, 2010).

${ }^{21}$ Ibid., 291-298.

${ }^{22}$ Mancur Olson, "Dictatorship, Democracy, and Development," American Political Science Review 87:3 (September 1993), p. 568.

${ }^{23}$ This concern is particularly acute in countries with a small pool of business-savvy elites. See Eric McGlinchey, Chaos, Violence, Dynasty: Politics and Islam in Central Asia (Pittsburgh: University of Pittsburgh Press, 2011). Additionally, the transactions costs of expropriating the assets of opponents might be higher than the potential benefits; capitalist elites often are more productive stewards of their assets than the state. See Olson, 1993, p. 571. 
${ }^{24}$ I am grateful to an anonymous reviewer for highlighting this point.

${ }^{25}$ This model departs slightly from Olson's conception of roving bandits as agents of unchecked violence. Even in resource-rich kleptocracies, violence is still confined to specific individuals and exercised with some restraint.

${ }^{26}$ See OSCE election monitoring reports: http://www.osce.org/odihr/elections

${ }^{27}$ US Energy Information Agency, Georgia Country Report, 2015.

${ }^{28}$ World Bank Enterprise Survey (2002); Alexander Kupatadze, "Explaining Georgia's Anti-Corruption Drive," European Security 21:1 (March 2012), p. 22.

${ }^{29}$ Personal interview with director of political NGO, Tbilisi Georgia, March 2009.

${ }^{30}$ Givi Targamadze, "Sixty Minutes Plays with Fire," Institute for War and Peace Reporting, June 9, 2000. Most information about corruption among ruling elites was released by Shevardnadze's political opponents, including Targamadze. Nonetheless, this information is widely considered to be accurate.

${ }^{31}$ David Darchiashvili, "Georgian Security: Challenged from Within and Without," in Phillip Fluri and David Darchiashvili, eds. After Shevardnadze: Georgian Security Sector Governance after the Rose Revolution (Geneva: Geneva Centre for the Democratic Control of Armed Forces, 2006).

${ }^{32}$ Zurab Chiaberashvili and Gigi Tevzadze, "Power Elite in Georgia: Old and New," in Philip Fluri and Eden Cole, eds., From Revolution to Reform: Georgia's Struggle with Democratic Institution Building and Security Sector Reform (Vienna: LeVak, 2005).

${ }^{33}$ Targamadze, 2000; "President Shevardnadze requests probe in nephew's alleged fraudulence," Sakinform news agency, September 24, 1998.

34 "Georgian President Calls for Implementation of Resolutions on Abkhazia," Georgian Radio, Tbilisi, March 31, 1998.

${ }^{35}$ Darchiashvili.

${ }^{36}$ World Bank, Fighting Corruption Public Services: Chronicling Georgia's Reforms (Washington DC: World Bank, 2012), p. 53-54.

${ }^{37}$ J. Anderson et al, Corruption in Georgia: Survey Evidence (Washington DC: World Bank, 2000).

${ }^{38}$ Personal interview with political expert, Tbilisi, Georgia, March 2009.

${ }^{39}$ Personal interviews with government officials, Tbilisi, Georgia, March 2009.

${ }^{40}$ These prosecutions were criticized as politically selective. "Shevardnadze's Relative Released after Paying \$15.5 Million," Civil Georgia, April 26, 2004; Chiaberashvili and Tevzadze, 2005.

${ }^{41}$ World Bank, World Development Indicators.

${ }^{42}$ Paul Manning, The Semiotics of Drinks and Drinking (New York: Continuum), p. 215.

${ }^{43}$ Chiaberishvili and Tevzadze.

${ }^{44}$ World Bank, World Development Indicators. See also World Bank, Enterprise Survey (2002), http://www.enterprisesurveys.org/

45 "Ex-Chief of State Audit Agency Sentenced to Pre-Trial Detention," Civil Georgia, April 24, 2004

${ }^{46}$ Interview with director of local NGO, Tbilisi, Georgia, March 2009.

47 "Georgian president says leading entrepreneur not to be spared if he breaks law," Kavkasia-Press, Tbilisi, July 19, 1999.

48 "Georgian president to lead new bloc to election victory," Georgian Radio, Tbilisi, April 7, 2003.

${ }^{49}$ As described in US Department of State's Human Rights Reports for 1995-2003.

50 "Shevardnadze cautious about illegitimate property expropriation law," Georgian Radio, Tbilisi, August, 13, 2001.

51 "Georgian President Warns against 'Witch-Hunting' in Fight Against Corruption," Georgian Radio Tbilisi, October 30, 2000.

52 "Shevardnadze cautious", 2001.

${ }_{54}^{53} 60.8 \%$ of Kazakh firms reported paying bribes in the World Bank Enterprise Survey (2002).

${ }^{54}$ Matthew Sagers, "The Oil Industry in the Southern-Tier Former Soviet Republics," Post-Soviet Geography, 35:5 (1994): 267-298.

${ }^{55}$ Worldwide, Kazakhstan ranks twelfth in oil endowment and fifteenth in gas reserves. See US Energy Information Administration's January 2015 report on Kazakhstan.

${ }^{56}$ Jones Luong and Weinthal

${ }^{57}$ Global Witness, "Time for Transparency: Coming Clean on Oil, Mining and Gas Revenues," March 2004; Seymour Hersch, "The Price of Oil," The New Yorker, July 9, 2001; United States of America v. James H. Giffen, US District Court, Southern District of New York, April 2, 2003 accessed at http://www.justice.gov/criminalfraud/case/united-states-v-james-h-giffen-et-al 
${ }^{58}$ Hersch.

${ }^{59}$ United States of America v. James H. Giffen; Ron Stodghill, “Oil, Cash and Corruption,” The New York Times, November 5, 2006.

${ }^{60}$ Floyd Norris, "Baker Hughes Admits to Overseas Bribery," The New York Times, April 27, 2007.

${ }^{61}$ Guy Chazan, "Kazakh Spat Casts Light on China Deals," The Wall Street Journal, March 26, 2010; Richard Orange, "Wikileaks: Kazakh billionaire who bought Duke of York's home has 'avarice for large bribes," The Telegraph December 1, 2010.

${ }^{62}$ Martha Brill Olcott, Kazakhstan: Unfulfilled Promise? Revised Edition (Washington: Carnegie Endowment, 2010), ch 10.

${ }^{63}$ EBRD, Transition Report 1999 (London: EBRD, 1999)

${ }^{64}$ Olcott, p. 139.

${ }^{65}$ Olcott, p. 138.

${ }^{66}$ Junisbai, 2012; Sebastien Peyrouse, "The Kazakh Neopatrimonial Regime: Balancing Uncertainties Among the 'Family,' Oligarchs, and Technocrats," Demokratizatsiya 20:4 (Fall 2012), 345-370.

67 “I believe in integrity in politics,' Governor of Kazakh Pavlodar Region,” BBC Monitoring June 2, 2001.

68 “Kazakh government allocates 50m dollars to support domestic industry,” Interfax-Kazakhstan, July 3, 1999.

69 “Kazakh Paper Profiles New Political Party Democratic Choice,” Novoye Pokolyeniye, November 30, 2001.

70 “Kazakh Premier Forecasts Further Government Reshuffle,” Interfax-Kazakhstan, December 21, 2000.

71 "Kazakhstan: European Parliament Singles Out Opposition Leader for Recognition,” Radio Free Europe/Radio Liberty, June 14, 2002.

72 Aldar Kusainov, "Nazarbayev-Zhakiyanov French Embassy Standoff Part of Broader Crackdown," Eurasianet, April 1, 2002.

${ }^{73}$ Gulnoza Saidazimova, "Nazarbaev Touts Stability in Run-up to Election," Radio Free Europe/Radio Liberty, November 14, 2005.

${ }^{74}$ Ibid.

75 "Kazakh President Merges Ministries, Makes New Appointments," Radio Free Europe/ Radio Liberty Kazakh Report, August 28, 2002; “Company Overview of Samruk-Kazyna National Welfare Fund,” Bloomberg Business, at http://www.bloomberg.com/research/stocks/private/person.asp?personId=60922909\&privcapId=51981064

${ }^{76}$ Ibragim Alibekov, "Opposition Leader in Kazakhstan Ordered Released from Prison," Eurasianet, August 11, 2004; Ibragim Alibekov, “Andijan Events Cause Kazahstani Officials to Re-examine Domestic Policies,” Eurasianet May 26, 2005.

77 "Kazakh opposition figure's firm closes to avoid allegations of bribery," Soz, August 5, 2004.

${ }^{78}$ Rupert Neate, "Kazakh billionaire to be extradited over alleged $£ 3$ bn fraud, French court rules," The Guardian, January 9, 2014

${ }^{79}$ See Zhakiyanov's LinkedIn page: https://www.linkedin.com/in/galymzhan-zhakiyanov-71a66040

${ }^{80}$ Aldar Kusainov, "Domestic Crackdown in Kazakhstan Could Have Economic Consequences," Eurasianet, August 5, 2002.

81 "Kazakh president says he cannot interfere in trial of opposition leaders," Interfax-Kazakhstan April 17, 2002

${ }^{82}$ Personal interview, director of local NGO, Almaty Kazakhstan, March 2008

${ }^{83}$ Luke Harding, "WikiLeaks cables condemn Russia as 'mafia state,"” The Guardian, December 1, 2010. http:/www.guardian.co.uk/world/2010/dec/01/wikileaks-cables-russia-mafia-kleptocracy. Luke Harding,

"WikiLeaks cables claim Vladimir Putin has secret wealth hidden abroad," The Guardian, December 1, 2010. http://www.guardian.co.uk/world/2010/dec/01/wikileaks-cables-vladimir-putin-claims.

${ }^{84}$ Karen Dawisha, Putin's Kleptocracy (New York: Simon \& Schuster, 2014).

${ }^{85}$ Anna Persson, Bo Rothstein, and Jan Teorell, "Why Anticorruption Reforms Fail—Systemic Corruption as a Collective Action Problem," Governance 26:3 (July 2013). 